\title{
“Rappaccini's Daughter” - Sources and Names
}

\author{
BURTON R. POLLIN
}

$\mathrm{R}$

APPAccini's Daughter has always been viewed as one of Hawthorne's strangest and most provocative tales. I should like to consider a few of the possible sources which serve chiefly to underscore the theme of the transformation or re-creation of human life, these being Mary Shelley's Frankenstein, Godwin's St. Leon, and Milton's Paradise Lost. Related to the supernatural motif of the story is the meaning in Italian of the names of four major characters.

That Hawthorne could not have failed to know Frankenstein has been assumed by R. P. Adams for "The Birthmark." 'Mary Shelley's first work was a celebrated, perhaps even notorious, novel during the period of Hawthorne's early development, and it continued to be popular throughout the century. There were to be at least nine reprints in English of this work of 1818, two of them published in the United States. ${ }^{2}$ The third edition of 1831, with a long new preface by the author, constituted the ninth of the popular "Standard Novels" of Colburne and Bentley. ${ }^{3}$ Hawthorne probably saw the 1833 Philadelphia reprint by the well-known firm of Carey and Lea, to which he had addressed a request in 1832 concerning an article for the Souvenir, one of its publications. ${ }^{4}$ Frankenstein is a distinguished specimen of the Gothic tale, a genre which was prominent in Hawthorne's reading. ${ }^{5}$ It has left its traces in The Scarlet

1 R. P. Adams in Tulane Studies, VIII (1958), 115-151, "Hawthorne: The Old Manse" - specifically, p. 132, footnote.

2 In London, 1823, 1831, 1856, 1882, 1886, 1888, 1897; in Philadelphia, 1833; and in Boston, 1869. The very reputable New-York Mirror, X (June 1 and 8, 1833), 378 and 390, carried two notices of the Philadelphia edition, calling it "widely known" and "justly admired by every reader of romance."

3 Both Shelley's preface of 1818 and this one try to establish the serious philosophical nature of the story and remove it from the sphere of the Gothic terror novel. Slightly abridged, this preface may be consulted in the Everyman edition.

4 See Moncure D. Conway, The Life of Nathaniel Hawthorne (London, 1895), p. 44.

5 See Mark Van Doren, Nathaniel Hawthorne (New York, 1949), pp. 34-35. 
Letter and The House of the Seven Gables as well as in a host of his short stories. ${ }^{6}$

Mary Shelley had dedicated her novel to her father, William Godwin, whose St. Leon (1799) was one of the most original of the Gothic romances and exploited the Rosicrucian themes of the elixir of life and the philosopher's stone giving the hero, St. Leon, unlimited power and also estrangement from all mankind. Hawthorne's earliest work, Fanshawe, and also his posthumous novels, show the evidences of Godwin's, three of which he had read with great admiration in 1820. He would very naturally turn from the father's to the daughter's fiction. Similarly, we know that Hawthorne's interest in the life and works of her poet-husband during the writing of Mosses from an Old Manse guided his attention, for the collection contains a very sensitive discussion of Shelley. ${ }^{8}$

Specific points of comparison for Frankenstein and "Rappaccini's Daughter" are the lust for knowledge and the anguished call for human companionship, both important also in Godwin's Caleb Williams and St. Leon. The two themes are also basic to Paradise Lost, a work whose characters and viewpoints permeate the work of Mary Shelley as well as the entire two volume collection of tales by Hawthorne. ${ }^{9}$ His most ambitious books were to make use of the misery resultant from intellectual pride and from social alienation. ${ }^{10}$

6 His debt to Gothic romances is given most fully by Arlin Turner, "Hawthorne's Literary Borrowings," PMLA, LI (1936), 543-562, and Jane Lundblad, "Nathaniel Hawthorne and the Tradition of Gothic Romance," No. IV of Essays and Studies on American Language and Literature (American Institute in the University of Upsala, Sweden, 1946). Neither one mentions Frankenstein.

7 This letter to Louisa of October 31, 1820 can be read in George Lathrop, $A$ Study of Hawthorne (Boston, 1876), p. 108, and also in Randal Stewart's edition of The American Notebooks (New Haven, 1932), p. lxxxii. See the latter work (pp. lxvi-lxvii and xciii for the general influence of Godwin's work; also Van Doren, op. cit., p. 35.

8 Mosses from an Old Manse (Boston, 1880), II, 151-153. All references in my text will be to this edition.

9 For Milton's epic in Frankenstein, see the author's study in Comparative Literature xvii (1965), 91-108; Richard Fogle in Hawthorne's Fiction (Norman, Oklahoma, 1952), pp. 99 ff. discusses Rappaccini as a "false god" derived from Paradise Lost, but ignores the prevalence of Milton's influence throughout the two volumes, as does Leo Marx in "The Machine in the Garden," New England Quarterly, XXIX (March, 1956), pp. 37 and 39-40.

10 For the link between knowledge and isolation in Hawthorne see Randall Stewart, Nathaniel Hawthorne (New Haven, 1948), p. 248, Hubert H. Hoeltje, In- 
In this tale the father is literally rapacious of knowledge (Italian "rapace"), even being ready to pervert his daughter's development so that she and her empoisoned "mate" will be able to live as the invulnerable parents of a "superior" race. The tale shares with Frankenstein the atmosphere of the university town: Padua and Ingolstadt in Bavaria, the home of Professor Adam Weishaupt, founder of the Illuminati.

In both works the relevant knowledge is derived from necromancy. In Frankenstein the scientist's interest in the creation of life is fostered through the works of Cornelius Agrippa, who is an important figure in "A Virtuoso's Collection" (Mosses, II, 281 and 291). The perversion of knowledge figures throughout "Rappaccini's Daughter," with the poisoned and poisoning flower created by the girl's father at her birth serving for Giacomo as the apple of knowledge; it is to be plucked when he has absorbed enough of her tainted presence. In Hawthorne the plant of knowledge is clearly the "fleur du mal," definitely identified with its "sister," the seductive woman. Elsewhere in Mosses he prefers to allude to Eve's "bridal rose" as her instrument of temptation; significantly, the flower is pressed between the leaves of Cornelius Agrippa's book (II, 291). The call of the flesh is found also in Frankenstein, with the scientist's pledge to his fiancée pitted against his obligation to the lovelorn monster, his Doppelgänger in estrangement. ${ }^{11}$ One might note that Frankenstein intended to create a beautiful being, but lacked the power to mould all of the flesh, especially the lips and eyes, into a pleasing human form (Chapter V).

Beatrice has her God-given beauty and loveliness of soul, but employed by her father she must assume the role of mentor, almost unconsciously. In this she resembles her namesake in Dante's epic; indeed her realm is a more limited inferno for the unsuspecting. Significantly, Dante's "Inferno" is mentioned in the first paragraph of the tale. ${ }^{12}$

ward Sky (Durham, 1962), p. 87, and Newton Arvin, Hawthorne (Boston, 1929), pp. 140 and 272.

11 Isolation is stressed by the necromancer in St. Leon (Chapter XIII) and becomes the major "moral" of the story; Godwin devoted a chapter to Cornelius Agrippa in his popular Lives of the Necromancers (London, 1834; New York, 1835 and 1847).

12 Hawthorne's unaccustomed indecision about the meaning of the ending of the tale and the real quality of Beatrice's soul is revealed in the conversation with 
Giovanni Guasconti interferes ultimately with the father's plan and, like Aylmer in "The Birthmark," destroys the beautiful creation with the antidote administered through kindness. Giovanni intends to impose a human reality or a new balance, but his name in Italian means a "meddler into affairs" ("guastaconti"). It is not certain that he conveys divine justice in the vial taken from Dr. Baglioni; for one thing, the latter may cherish a grudge against Rappaccini for his superior learning. Hawthorne's last words imply this: "Baglioni looked forth from the window, and called loudly, in a tone of triumph mixed with horror.... "Rappaccini! Rappaccini! and is this the upshot of your experiment" (p. 149).

Ambiguity of characterization inheres also in the origin of his name, which may be derived from "sbagliare" ("to err") or "bagliore" ("a flash of light")..$^{13}$ Beatrice's name has the same ambivalence, since she is rather the accursed than the blessed one. There is justification in imputing to Hawthorne a deliberate use of the resources of Italian in these appellations. He had been tutored by Benjamin Lynde Oliver, known for his knowledge of Italian and his skill in the use of scientific apparatus, thought by some to be the original of Dr. Rappaccini as well as Dr. Grimshawe and Dr. Dolliver. ${ }^{14}$ Later opportunities to learn or to apply Italian came with his 1841 sojourn at Brook Farm, where Sophia Ripley held a Dante class in Italian. ${ }^{15}$ Moreover, Hawthorne's wife Sophia was a gifted linguist who had studied Italian. His son Julian reported the unusual circumstance that Hawthorne read to her the unfinished tale and discussed his indecision about the ending. ${ }^{16}$ Thus, there was ample opportunity for him to consult with her about the significance of the names in "Rappaccini's Daughter."

This element helps to underscore the allegorical nature of the plot, so reminiscent of Paradise Lost. It is found even in the Introduction, reprinted from the December, 1844, issue of the Demo-

his wife reported by Julian Hawthorne in Nathaniel Hawthorne and His Wife (Cambridge, 1884), I, 360-361.

13 Of course, it may be derived from Padua's river, the Berchiglione. In fact, the Baglioni family of Calvi in Corsica had long been active in Italian political history, e.g., Malatesta and also G. P. Baglioni.

14 See Robert Cantwell, Nathaniel Hawthorne (New York, 1948), p. 55.

15 Ibid., p. 326.

16 For Sophia's study of Italian see Julian Hawthorne, op.cit., I, 62. 
cratic Review and purporting to be "from the writings of Aubépine," i.e., Hawthorne (p. 107); he pretends to be the author of a book which bears the same title as a story in Mosses: "Le nouveau Père et la nouvelle Mère Eve."17 In "Rappaccini's Daughter" itself the garden is of "earlier date ... than anywhere in the world" (p. 110). "Was this garden, then, the Eden of the present world? And this man ... was he the Adam?" (p. 112). About Beatrice, Hawthorne wrote, "It mattered not whether she were angel or demon..., he was irrevocably within the sphere." The plant to which she is "sister" is "no longer of God's making, but the monstrous offspring of man's depraved fancy..." (p. 128). When Beatrice called Giovanni, "he hastened into that Eden of poisonous flowers" (p. 134). When she is expiring, she speaks of the poisonous flower, "which will no longer taint my breast among the flowers of Eden" (p. 148). It might be added that the use of variations on the word "monster" throughout may be reminiscent of Frankenstein, which also stresses the miscreating "man of science" (pp. 122, 128, 135, 144, and 145).

The lost Eden theme in Hawthorne's thoughts can be traced from his earliest years and into his most mature works. The importance of Milton's writings can be verified from the many references in his notebooks.18 Throughout the two volumes of Mosses there are references to forbidden fruit, Eden, Milton's poetry, and the devilish serpent. ${ }^{19}$ In addition to the flower of passion theme, there is fictional use of attempts to play the creator through the construction of living beings. This theme was given its classic form in the Ovidian myths of Pygmalion and Prometheus, as Frankenstein's subtitle and epigraph from Milton show. Again and again Hawthorne's mind lingered over this notion in his Mosses: in "The Birthmark" (I, 49), "Feathertop" (I, 259ff.), "The Christmas Banquet" (II, 49), "Drowne's Wooden Image" (II, 82 and 87), "The Artist of the Beautiful" (II, 260 and 269), and "Rappaccini's Daughter"

17 See Cantwell, op.cit., p. 202, for the 1837 joke of the Frenchman, M. Schaeffer, in calling Hawthorne "M. de l'Aubépine."

18 See The American Notebooks (Boston, 1896), pp. 33, 39, 297, and 354 for Eden references; see also references to Milton in The French \& Italian Notebooks, Vol. X of The Complete Works (Boston, 1871), 93, 278, and 308.

19 For these themes see Mosses, I, 7, 15-17, 45, $106 \mathrm{ff}$., 201; II, $5 \mathrm{ff} ., 32,49,84$, $155-156,210,264,277$, and 291. 
(I, $106 \mathrm{ff}$.$) . It is consonant with Hawthorne's interest in the elixir$ of life, which runs throughout the body of his works. His early tale, "Dr. Heidegger's Experiment," attempts to treat the Rosicrucian fancy with suitable mockery, but the elixir vitae plays a role in two of the unfinished novels that were to be published posthumously. ${ }^{20}$ There was an underlying ambivalence throughout the tale of the Italian scientist and many other works by Hawthorne: a desire for the fruits of science to counteract man's natural weakness of condition and a fear to tamper with the circumstances arranged by God or nature.

Other strands and sources were woven into the story: the tale of the poisoned girl sent to Alexander the Great is mentioned by Hawthorne (pp. 135-136) without the attribution to Sir Thomas Browne supplied by Julian Hawthorne and others, ${ }^{21}$ and Hoffmann's story, "Datura Fastuosa," has been suggested by another writer. ${ }^{22}$ Above all, however, Milton, Godwin, and Mary Shelley appear to have provided the most substantial ingredients for the brew in the alembic of the artist's imagination.

Bronx Community College of

The City University of New York

20 For the theme in Septimus Felton and The Dolliver Romance see Henry Davidson, ed., Hawthorne's Dr. Grimshawe's Secret (Cambridge, 1954), p. v. and Randall Stewart, ed., The American Notebooks... (New Haven, 1932), pp. IxxxiiIxxxvi.

21 Julian Hawthorne, Hawthorne's reading (Cleveland, 1902), p. 80 and Arlin Turner in PMLA, LI (1936), 543-562, specifically, 554-555.

22 Jane Lundblad, Nathaniel Hawthorne and European Literary Traditions (Upsala, 1947), p. 148. 